IZABELA CZAJA

Uniwersytet Ekonomiczny w Krakowie, Polska - Cracow University of Economics, Poland

TOMASZ KafEL

Uniwersytet Ekonomiczny w Krakowie, Polska - Cracow University of Economics, Poland

\title{
Pomiar wdrażania koncepcji przedsiębiorczego uniwersytetu
}

\section{Measuring the Implementation of the Entrepreneurial University Concept}

Streszczenie: Uniwersytet przedsiębiorczy jest koncepcją opisywaną w związku z określeniem roli edukacji, badań naukowych, transferu wiedzy i współpracy z szeroko rozumianym otoczeniem w zakresie rozwoju społeczno-ekonomicznego i kulturowego, którego podstawą powinna stać się szeroko rozumiana przedsiębiorczość. Koncepcja ta staje się szczególnie istotna, ponieważ przedsiębiorczość wskazana została jako jedna z głównych kompetencji na europejskim rynku pracy, co nakłada na edukację obowiązek kształtowania postaw przedsiębiorczych ludzi w całym procesie edukacyjnym. Głównym celem artykułu jest popularyzacja koncepcji przedsiębiorczego uniwersytetu oraz kwestionariusza HEInnovate, który jest narzędziem służącym do oceny poziomu przedsiębiorczości jednostek szkolnictwa wyższego. W artykule przedstawiono analizę przypadku Uniwersytetu Ekonomicznego w Krakowie (UEK) przygotowaną na podstawie badań bezpośrednich (wywiady, obserwacje uczestniczące) oraz pośrednich (przegląd dokumentacji). Metodą badawczą wybraną w celu określenia poziomu przedsiębiorczości w ośmiu wyselekcjonowanych wymiarach działalności uniwersytetu jest kwestionariusz HEInnovate. Wyniki badań ankietowych przeprowadzonych wśród sędziów wartościujących omówione zostały z odniesieniem do wzorcowego modelu przedsiębiorczego uniwersytetu. Wskazane zostały obszary przedsiębiorczości UEK, które wymagają podjęcia działań usprawniających, prowadzących do tworzenia środowiska sprzyjającego kształtowaniu postaw przedsiębiorczych wewnątrz instytucji szkolnictwa wyższego (HEI), jak i w relacjach zewnętrznych (lokalnych, krajowych i międzynarodowych).

\footnotetext{
Abstract: The entrepreneurial university is a concept described in connection with the definition of the role of education, scientific research, knowledge transfer and cooperation with the broadly understood environment in the field of socio-economic and cultural development, which should be based on broadly understood entrepreneurship. This concept becomes particularly important since entrepreneurship was indicated as one of the main competences on the European labour market, which imposes on education the obligation to shape entrepreneurial attitudes of people throughout the entire educational process. The main goal of the article is to promote the concept of an entrepreneurial university and to disseminate the HEInnovate questionnaire as a tool for assessing the entrepreneurship of higher education units. The article presents a case study of the Cracow University of Economics (UEK) prepared on the basis of direct (interviews, participating observations) and indirect (review of documentation) research. The
} 
research method chosen to determine the level of entrepreneurship in the eight selected dimensions of the university's activity is the HEInnovate questionnaire. The results of surveys conducted among the value judges were discussed with reference to the model entrepreneurial university. The areas of UEK entrepreneurship have been indicated, which require undertaking improvement actions leading to the creation of an environment conducive to shaping entrepreneurial attitudes inside HEIs as well as in external relations (local, national and international).

Słowa kluczowe: HEInnovate (kwestionariusz); kompetencja; metoda studium przypadku; przedsiębiorczość; przedsiębiorczy uniwersytet

Keywords: case study method; competence; entrepreneurial university; entrepreneurship; HEInnovate questionaire

Otrzymano: 25 października 2019

Received: 25 October 2019

Zaakceptowano: 18 maja 2020

Accepted: 18 May 2020

\section{Sugerowana cytacja/Suggested citation:}

Czaja, I., Kafel, T. (2020). Pomiar wdrażania koncepcji przedsiębiorczego uniwersytetu. Przedsiębiorczość - Edukacja [Entrepreneurship - Education], 16(1), 144-158. doi: 10.24917/20833296.161.12

\section{Wstęp}

Uniwersytety doświadczają zmian i dostosowują paradygmaty swoich działań do aktualnych warunków działalności. Historyczny rozwój uniwersytetów jest ilustracją transformacji uczelni i ich ewolucji od modelu tradycyjnego, naukowego i finansowanego przez instytucję rządową, modele mieszane ukierunkowane na badania naukowe i współpracę z przemysłem i otoczeniem, aż po modele umiędzynarodowione, oparte na innowacjach, zorientowane na przedsiębiorczość, współpracujące w zakresie transferu wiedzy oraz współpracujące z międzynarodowymi korporacjami (Sułkowski, 2014; Wissema, 2009). Można wyróżnić co najmniej trzy modele uniwersytetu, które ilustrują jego funkcjonowanie na rynku i zależą od niego. Są to: uniwersytet pierwszej generacji - oparty na nauce, uniwersytet drugiej generacji - oparty na nauce i badaniach oraz uniwersytet trzeciej generacji - oparty na nauce, badaniach, transferze wiedzy i komercjalizacji (Makieła, 2017; Wissema, 2009). W ostatnich dekadach zmieniające się, dynamiczne środowisko doprowadziło do transformacji uniwersytetów - od doskonałości indywidualnej opartej na ciekawości do doskonałości społecznej opartej na wiedzy (Gibb i in., 2009). Przyjęły one nową rolę i stały się inkubatorem nauki, nowej wiedzy oraz technologii. Podjęły działalność komercyjną w celu transferu do gospodarki wyników swoich badań i wiedzy (Borch, Rasmussen, 2010; Shane, 2004; Wissema, 2009). Podstawowa rola uniwersytetu jest ściśle związana z przekazywaniem wiedzy, dlatego ważne jest, żeby uniwersytety edukację traktowały jako priorytet w swoich strategiach rozwoju (Sułkowski, 2014; Zioło, 2016). Za przedsiębiorcze uniwersytety uważa się takie, które w sferze edukacji wdrażają nowoczesne metody translearningu (e-learningu) i technologie cyfrowe podnoszące kompetencje cyfrowe wymagane na rynku pracy (Glachant, Haywood, Zorn, 2018; Hytti, Blackburn, Laveren, 2018), a także te, które wprowadzają istotne i elastyczne zmiany w kulturze organizacyjnej uniwersytetu, w nowej wizji i transformacji tożsamości uniwersytetu oraz w systemie zatrudniania wykładowców (Gjerding i in., 2006; Sporn, 
1996). Rozwój szkolnictwa wyższego spowodował zmianę wykraczającą poza kolegialne podejście do zarządzania w kierunku modeli łączących autonomię z samorządnością na niższych poziomach struktury organizacyjnej. Aby uniwersytet mógł stać się bardziej przedsiębiorczą instytucją, zarząd uczelni powinien utworzyć odpowiednie struktury zachęcające do przedsiębiorczości (Friedman, Silberman, 2003), zadbać o odpowiednią infrastrukturę (Gjerding i in., 2006) oraz zastosować profesjonalny, zdecentralizowany styl zarządzania (Debackere, Veugelers, 2005; Drucker, 1986). Strategie działania współczesnych uniwersytetów powinny uwzględniać efekty ich oferty edukacji i ich wpływ na rynek pracy, np.: możliwości zatrudnienia, rozwój umiejętności przedsiębiorczych i dostosowanie wykształcenia absolwentów do wymagań pracodawców (Andrews, Nicoletti, Timiliotis, 2018; Jørgensen, 2019; Komisja Europejska, 2003; Meyer-Guckel i in., 2019; Rachwał, 2019). Wspólną cechą wielu koncepcji współczesnego uniwersytetu staje się ściślejsza współpraca z przemysłem i interesariuszami (Watson, 2010). Stąd uniwersytet traktowany jest jako centrum innowacji i wiedzy odgrywające istotną rolę w określaniu dynamiki wzrostu w gospodarkach krajowych i regionalnych oraz źródło efektów i korzyści dla przemysłu (Acs i in., 2009; Altmann, Ebersberger, 2013). Uniwersytet jako element modelu potrójnej (Etzkowitz, Leydesdorff, 1999), poczwórnej (Kusio, 2019), a nawet pięciokrotnej helisy (Carayannis, Barth, Campbell, 2012) w układzie: uniwersytet-przemysłrząd-społeczeństwo-środowisko buduje ekologicznie odpowiedzialny „świat społeczno-techniczny”. Z kolei w ujęciu rozwoju skali układów przestrzennych (lokalnej, krajowej i międzynarodowej) uniwersytet stanowi element ekosystemu edukacji, transferu wiedzy i informacji (Kwiek, 2013; Zioło, 2016). Dzieje się tak za sprawą rozpowszechniania informacji i wiedzy na poziomie lokalnym i dzięki lokalnym uniwersytetom oraz sieciom społecznościowym, które są bardziej rozwinięte niż na poziomie krajowym i międzynarodowym (Agrawal, 2006). Uniwersytety znajdują się pod rosnącą presją wdrożenia zasad rynkowych obejmujących: prywatyzację, przedsiębiorczość, normalizację, zrównoważony rozwój, które to czynniki mogą wykluczać realizację ich historycznych celów bądź zmniejszać rolę tradycyjnych wartości i osłabiać autonomię wydziałów (OECD, 2012; Segrera, 2010; Sułkowski, 2014; Zioło, 2016). Przedsiębiorcze uniwersytety mogą utracić swoją autonomię, jeśli polegać będą wyłącznie na działalności przedsiębiorczej i komercyjnej (Slaughter, Leslie, 1997). Powinny być bowiem postrzegane również jako ośrodki przechowujące świadectwa kultury i wiedzy, związane z lokalnym środowiskiem naukowym i społecznościami, kultywujące tradycje edukacyjne (Zioło, 2016). Celem artykułu jest upowszechnienie koncepcji przedsiębiorczego uniwersytetu oraz możliwości pomiaru i oceny przedsiębiorczości jednostek szkolnictwa wyższego. Autorzy przyjęli hipotezę, że kwestionariusz HEInnovate nie tylko pozwala na postawienie diagnozy badanego uniwersytetu, ale także sprzyja wdrażaniu koncepcji przedsiębiorczego uniwersytetu, dzięki zawartym w instrukcji kwestionariusza wzorcowym rozwiązaniom.

\section{Koncepcja przedsiębiorczego uniwersytetu}

Uniwersytet przedsiębiorczy może być definiowany jako uniwersytet zdolny do zmian organizacyjnych oraz programowych (Drucker, 1986). W tym znaczeniu jest traktowany jako typ organizacji przedsiębiorczej działającej w duchu przedsiębiorczości Schumpeterowskiej, która polega na celowym, ale incydentalnym wprowadzaniu innowacji w swoich działaniach. Co znaczy, że poza okresami wprowadzania zmian uniwersytet działa 
rutynowo. Istota przedsiębiorczej organizacji, w tym uniwersytetu, zawiera się jednak w stałej dynamice działania w turbulentnym otoczeniu (Clark, 2004b). Stąd koncepcja przedsiębiorczego uniwersytetu nawiązuje do dynamicznej organizacji, stale uczącej się, nadążającej za zmianami, rozwijającej się w działaniach pozaedukacyjnych. W taki właśnie sposób została przedstawiona w dokumentach Unii Europejskiej w ostatnich latach (Zalecenia, 2018). Chociaż koncepcja przedsiębiorczego uniwersytetu nie jest innowacyjna, naukowcy nadal pracują nad zdefiniowaniem ideału nowoczesnego modelu uniwersyteckiego (Gibb, 2013a, 2013b; Gibb i in., 2009). Organizacje opisane w literaturze jako przedsiębiorcze uniwersytety w USA w latach 70. XX w. były przygotowane na zwiększony napływ. Dokładna ocena danych demograficznych, uwzględniająca rozkład wiekowy grup ludności, podejmowanie ryzyka, przygotowanie kadry i programy dla nowych studentów przyniosły tym uniwersytetom wzrost liczby studentów i wysokie pozycje w rankingach. Za przedsiębiorczy uniwersytet uważano wówczas instytucję edukacyjną opierającą się na strategii biznesowej, opracowanej na podstawie danych ze środowiska i wynikającej z analizy danych demograficznych (Drucker, 1986).

Szeroki przegląd piśmiennictwa na temat rozwoju uniwersytetu wskazuje kilka pojęć najczęściej opisujących koncepcję przedsiębiorczego uniwersytetu, wśród których znajdujemy np.: uniwersytety przedsiębiorcze (Williams, 1992), uniwersytety przedsiębiorcze i innowacyjne (Clark, 1998, 2001, 2004a), samodzielne i odnoszące sukcesy uniwersytety (Shattock, 2010) i uniwersytety adaptacyjne (Sporn, 1996). Przedsiębiorcza uczelnia jest „konstrukcją zarządzającą" zajmującą się prowadzeniem uniwersytetu (Olearnik, Pluta-Olearnik, 2015), wyróżniającą się: orientacją ekonomiczną (mierzoną np. efektywnością inicjatyw), orientacją rynkową (mierzoną np. dostosowaniem oferty edukacyjnej do rynku pracy), orientacją innowacyjną (mierzoną np. ilością nowych programów nauczania), orientacją menedżerską (mierzoną np. ilością pozyskiwanych talentów) (Pluta-Olearnik, 2009).

Przedsiębiorczość została wskazana jako jedna z ośmiu najważniejszych - kluczowych - kompetencji w systemie edukacji oraz na rynku pracy w przyszłości. Według nowych zaleceń Unii Europejskiej do kompetencji tych należą cztery kompetencje podstawowe: w zakresie rozumienia i tworzenia informacji, w zakresie wielojęzyczności, w zakresie nauk matematycznych, przyrodniczych, technologii i inżynierii oraz w zakresie cyfryzacji, a także cztery kompetencje przekrojowe: osobiste, społeczne i w zakresie umiejętności uczenia się, obywatelskie, w zakresie przedsiębiorczości, w zakresie świadomości i ekspresji kulturalnej (Zalecenia, 2018; Rachwał, 2019; Dębowski, Stęchły, 2019). Kształcenie kompetencji przedsiębiorczości powinno zatem odbywać się na wszystkich etapach edukacji, w tym w jednostkach szkolnictwa wyższego.

\section{Narzędzie HElnnovate do oceny poziomu przedsiębiorczości uniwersytetu}

W przeszłości uniwersytety były oceniane głównie na podstawie kryteriów jakościowych, takich jak: reputacja, opinie, znane nazwiska absolwentów, którzy zyskali renomę lub badaczy prowadzących znaczące badania. W miarę wzrostu liczby uniwersytetów porównywanie ich statusu i poziomu wykształcenia stało się trudniejsze oraz bardziej złożone. Brakuje również narzędzi, które można wykorzystać do oceny poziomu ich przedsiębiorczości.

W ostatnich latach Komisja Europejska i OECD opracowały narzędzie do samooceny dla szkół wyższych. Kwestionariusz HEInnovate, bo o nim mowa, pozwala zdiagnozować 
obecną sytuację uniwersytetu i potencjał jego przedsiębiorczości w ośmiu obszarach działania. Narzędzie to powstało w celu zapewnienia instytucjom szkolnictwa wyższego ram pomocnych w identyfikowaniu ukrytych szans i strategicznym rozwijaniu potencjału przedsiębiorczego i innowacyjnego uniwersytetów (HEInnovate, 2018). Stwarza ono możliwość oceny poziomu przedsiębiorczości badanego uniwersytetu (najwyższe noty i warunki wskazane $\mathrm{w}$ ocenianych $\mathrm{w}$ kwestionariuszu obszarach pozwalają na zarysowanie wzorca idealnego przedsiębiorczego uniwersytetu) i w pewnym stopniu pozwala na ocenę uniwersytetu w konkretnych obszarach działalności oraz ocenę poziomu jego przedsiębiorczości. Wysoki poziom przedsiębiorczości osiągany będzie w jednostkach, w których respondenci wskażą najwyższe noty (maksymalnie 5 punktów) w zakresie: 1. przywództwa i zarządzania, 2. zdolności organizacyjnych, 3. przedsiębiorczego nauczania i uczenia się, 4. przygotowywania i wspierania przedsiębiorców, 5. transformacji i zdolności cyfrowych, 6. wymiany wiedzy i współpracy, 7. wymiaru międzynarodowego i 8. mierzenia wpływu zmian w wyżej wymienionych obszarach.

Zgodnie $\mathrm{z}$ tym narzędziem wzorcowy uniwersytet przedsiębiorczy wykazuje zaangażowanie i podejmuje działania wskazujące na długofalowe zobowiązanie do budowania wewnętrznego środowiska i kształtowania zewnętrznych relacji na podstawie (idei) przedsiębiorczości (HEInnovate, 2018). Po pierwsze, w opisie misji takiego uniwersytetu zapisano, że przedsiębiorczość jest kluczowym celem wpływającym na wszystkie podejmowane przez uniwersytet działania. Ponadto istnieje zaangażowanie, koordynacja i integracja na wysokim poziomie hierarchii organizacyjnej w celu opracowania agendy przedsiębiorczości. Po drugie, działania na rzecz przedsiębiorczości są wspierane przez wiele trwałych źródeł finansowania i inwestycji. Uniwersytety tworzą zdolności i kulturę, zatrudniają osoby z duchem przedsiębiorczości w swoim zachowaniu i doświadczeniu oraz inwestują w rozwój pracowników. Po trzecie, uczelnia zapewnia formalne i nieformalne możliwości uczenia się oraz współpracuje z wszystkimi interesariuszami w celu wspierania badań w zakresie przedsiębiorczości. Doświadczenie biznesowe jest zintegrowane z kursami edukacyjnymi. Po czwarte, zapewnia się wsparcie studentom, pracownikom, absolwentom i osobom trzecim zainteresowanym opracowywaniem pomysłów biznesowych, a także szkolenia i mentoring prowadzone przez doświadczone osoby ze środowisk akademickich lub przemysłowych. Uczelnia ułatwia też dostęp do finansowania i inkubacji przedsiębiorstw. Po piąte, zakłada się, że otwarta nauka, praktyka innowacji, e-learning, cyfrowe systemy nauczania i komunikacji za pośrednictwem IT są szeroko rozpowszechnione w uczelniach. Uniwersytet wdraża nowe technologie cyfrowe, które prowadzą do innowacji i przedsiębiorczości we wszystkich działaniach w ramach organizacji. Po szóste, uniwersytet jest zaangażowany w aktywne partnerstwo, współpracę i wymianę wiedzy z zewnętrznymi partnerami: przemysłem, sektorem publicznym, zainteresowanymi stronami i społeczeństwem. Dzięki współpracy z inkubatorami biznesu, parkami naukowymi i centrami projektów uniwersytet integruje działalność badawczą, edukacyjną i przemysłową w celu wykorzystania i wymiany nowej wiedzy. Po siódme, uczelnia jest międzynarodową instytucją, która wspiera mobilność międzynarodową w obu kierunkach: do wewnątrz - dla pracowników przedsiębiorczych i na zewnątrz dla pracowników i studentów. Ostatecznie, po ósme, przedsiębiorczy uniwersytet jest w stanie ocenić i zmierzyć wykonanie planu oraz wpływ działań w obszarze przedsiębiorczości. Oznacza to, że uniwersytet ocenia działania przedsiębiorcze we wszystkich obszarach wyróżnionych w kwestionariuszu HEInnovate (HEInnovate, 2018). Koncepcja 
przedsiębiorczej uczelni rozwija się, a niektóre aspekty działalności uczelni w odniesieniu do przedsiębiorczości można zmierzyć za pomocą narzędzia HEInnovate. Jednak idealny uniwersytet przedsiębiorczy powinien być w stanie opracować własne metody pomiaru wyników pracy personelu czy realizacji strategii i planu rozwoju wraz ze wskazaniem ich wpływu na rozwój przedsiębiorczości. Ograniczenia badań nad oceną skuteczności kwestionariusza HEInnovate nie pozwalają ustalić, czy narzędzie to jest odpowiednie do dokonywania przyszłych porównań osiągnięć uniwersytetów w dążeniu do doskonałości. Ponieważ do tej pory jest to jedyne dostępne narzędzie do samooceny uczelni w uzyskiwaniu idealnego kształtu uniwersyteckiej przedsiębiorczości, należy przeprowadzić więcej badań.

\section{Metodyka badań obszarów przedsiębiorczości uniwersytetu}

Analiza literatury poświęconej ewolucji roli uniwersytetu skłoniła autorów do podjęcia badań w ich macierzystej jednostce, którą jest Uniwersytet Ekonomiczny w Krakowie (dalej: UEK). Celem badań była próba oceny wdrażania idei przedsiębiorczego uniwersytetu, w szczególności inicjatyw dotyczących rozwoju działalności edukacyjnej, współpracy gospodarczej oraz roli przedsiębiorczości, w funkcjonowaniu UEK. Wybór strategii badawczej na podstawie metody studium przypadku podyktowany został kilkoma względami. Punktem wyjścia była możliwość wykorzystania w procesie badawczym określonych ram teoretycznych, w tym wypadku koncepcji przedsiębiorczego uniwersytetu. Niezmiernie istotną przesłanką wyboru metody studium przypadku była możliwość testowania modelu badawczego, a w konsekwencji - lepszego zrozumienia wskazanych czynników i wzajemnych relacji, jak również modyfikacji i uzupełnienia wskazanych luk poznawczych i dopracowanie teorii (Ćwiklicki, Pilch, 2018; Haller, Stott, 2010; Yin, 2015). Uzasadnieniem wyboru był również fakt, że studium przypadku może obejmować różne orientacje epistemologiczne i pozwala na łączenie ilościowych i jakościowych technik badawczych (Ćwiklicki, Pilch, 2018; Yin, 2015). Okolicznością przemawiającą za wyborem tej metody badawczej była również możliwość opracowania, z jej pomocą, praktycznych rozwiązań (Matejun, 2012). W badaniu autorzy zastosowali tzw. eksploracyjne studium pojedynczego przypadku, które pozwala na wstępne rozpoznanie przedmiotu badania oraz formułowanie zagadnień i strategii przyszłych badań (Yin, 2015). Przeprowadzone przez autorów studium ma również charakter tzw. instrumentalnego studium przypadku. Przypadek taki pełni funkcję pomocniczą - jest wybierany, ponieważ stanowi ilustrację jakiegoś ważnego z punktu widzenia badacza problemu (Mizerek, 2017). Jego analiza rozpatrywana jest $\mathrm{z}$ wielu punktów widzenia oraz przy uwzględnieniu perspektyw teoretycznych, umożliwia zrozumienie badanego problemu. Uwzględniając klasyfikację studium przypadku, można uznać, że zastosowano tzw. ewaluacyjne podejście, które ma na celu przede wszystkim „określenie wartości programu lub projektu, który stanowi o rozpatrywanym przypadku”. Przyjęta perspektywa aksjologiczna ma zasadnicze znaczenie, gdyż na jej podstawie badacz musi określić, w jakim stopniu badany przypadek realizuje przyjęte wartości, a następnie naukowiec musi upublicznić wyniki swoich badań (Mizerek, 2017).

Etapy prowadzonego przez autorów badania wyznaczyła metodyka stosowania analizy przypadku proponowana przez W. Czakona (2006), na którą składały się następujące etapy: zdefiniowanie pytań badawczych, dobór przypadków, wybór narzędzi 
gromadzenia danych, zebranie danych, analiza danych, kształtowanie uogólnień, konfrontacja wyników badania z literaturą, sformułowanie uogólnień. Kluczowe pytanie, na które autorzy próbowali znaleźć odpowiedź, brzmiało: czy UEK wdraża koncepcję przedsiębiorczego uniwersytetu zgodnie $\mathrm{z}$ wymiarami proponowanymi $\mathrm{w}$ kwestionariuszu HEInnovate. Celem badań było również ustalenie obszarów wymagających intensyfikacji działań w zakresie wdrażania tej koncepcji oraz przygotowanie propozycji w tym zakresie. Celowo ograniczono badania do macierzystej jednostki, gdyż zwiększało to szanse na wykorzystanie metody triangulacji danych przez dostęp do dokumentów, przychylność respondentów, obserwacje uczestniczącą i doświadczenia własne. Należy jednak dodać, że badanie miało charakter pilotażowy i było ostateczną próbą przed właściwym badaniem obejmującym większą liczbę respondentów, a także przypadków. Przygotowanie warstwy teoretycznej badań polegało na studiowaniu źródeł wtórnych: wcześniejszych badań i analiz, dokumentów rządowych, a także artykułów związanych z koncepcją przedsiębiorczego uniwersytetu opublikowanych w czasopismach naukowych, zarówno krajowych, jak i zagranicznych. Badanie to obejmowało obszerny przegląd literatury, w którym krytycznie przeanalizowano obecny stan oraz perspektywy wiedzy w tym zakresie. W pierwszym etapie badań w drodze wywiadów bezpośrednich z pracownikami naukowo-dydaktycznymi UEK uzyskane zostały informacje o rozproszonych, jednakże licznych inicjatywach o charakterze przedsiębiorczym. Na ich podstawie zostały opracowane najlepsze praktyki odpowiadające obszarom przedsiębiorczości ocenianym w kwestionariuszu HEInnovate (Czaja, Kafel, 2019).

Kluczowym narzędziem badawczym zastosowanym do zebrania informacji i określenia poziomu wdrażania koncepcji przedsiębiorczego uniwersytetu był kwestionariusz HEInnovate, będący narzędziem techniki ankietowej zastosowanej w metodzie sondażu diagnostycznego. Wykorzystano również rezultaty badań bezpośrednich (wywiady, obserwacje uczestniczące) oraz pośrednich (przegląd dokumentacji). Autorzy, na podstawie konsultacji z badaczami reprezentującymi inne uniwersytety, zastosowali celowy dobór próby badawczej. Wśród próby badawczej (10 tzw. sędziów wartościujących) znalazły się m.in. osoby pełniące funkcję prorektora, dziekana oraz kierownicy jednostek i komórek odpowiedzialnych za współpracę uczelni z praktyką gospodarczą, a także członkowie Komisji Senackiej, w tym przedstawiciel studentów. Kwestionariusz ankiety HEInnovate został wydrukowany i dostarczony każdemu z sędziów wartościujących wraz z informacją o anonimowości odpowiedzi. Badacze wyjaśnili sędziom wartościującym konstrukcję narzędzia i zasady udzielania odpowiedzi na pytania kwestionariusza HEInnovate oraz uczestniczyli (w większości wypadków) w jego wypełnianiu. Odpowiadając na pytania dotyczące każdego z wymiarów, uczestnicy badania mieli wskazać, czy UEK stosuje takie wzorcowe rozwiązania (ocena bliższa 5.0 - w skali od 1.0 do 5.0), czy wręcz przeciwnie - nie udało mu się sprostać wymogom stawianym w tym wymiarze (ocena bliższa 1.0). Wywiad uczestniczący stworzył możliwość uzyskania dodatkowych informacji (np. na temat przedsiębiorczych inicjatyw, działań, projektów, grantów oraz dobrych praktyk stosowanych w UEK) i był cenny ze względu na końcowe rezultaty badania. Następnym krokiem w procedurze badania studium przypadku UEK była analiza zgromadzonych danych, polegająca na uporządkowaniu zebranego materiału, a następnie jego hierarchizacji zgodnie z oceną przydzieloną poszczególnym wymiarom przez sędziów wartościujących (obliczono średnią wyników uzyskanych w ramach całej badanej zbiorowości). Wyniki badań ankietowych przeprowadzonych wśród wybranych sędziów 
wartościujących, omówione z odniesieniem do wzorcowego modelu przedsiębiorczego uniwersytetu, pozwoliły na opracowanie wstępnej diagnozy UEK w kontekście wdrażania koncepcji przedsiębiorczego uniwersytetu. Wskazane zostały trzy najsłabiej ocenione obszary przedsiębiorczości UEK, które wymagają szczególnej uwagi i podjęcia działań usprawniających, prowadzących do tworzenia środowiska sprzyjającego budowaniu relacji i kształtowaniu postaw przedsiębiorczych.

\section{Wyniki badań}

Opinia uczestników badania na temat implementacji koncepcji przedsiębiorczego uniwersytetu w Uniwersytecie Ekonomicznym w Krakowie nie wypadła zbyt pozytywnie (rycina 1). Spośród ośmiu rozpatrywanych wymiarów oceny jednostki, tylko w jednym przypadku, a mianowicie w wymiarze: „wymiana wiedzy i współpraca”, uzyskana ocena przekroczyła ocenę dostateczną (uzyskując ocenę $3.1 \mathrm{w}$ skali od 1 do 5 , gdzie ocena 5 oznaczała najwyższy poziom realizacji wymogów stawianych w danym wymiarze). Oznacza to, że zdaniem respondentów badana jednostka w umiarkowanym stopniu realizuje swoją "trzecią misję” i pobudzanie czy bezpośrednie wykorzystywanie wiedzy na rzecz społecznego, kulturowego i gospodarczego rozwoju społeczeństwa nie ma w niej charakteru stałego procesu.

Rycina 1. Ocena wdrażania koncepcji przedsiębiorczego uniwersytetu w wynikach kwestionariusza HEInnovate

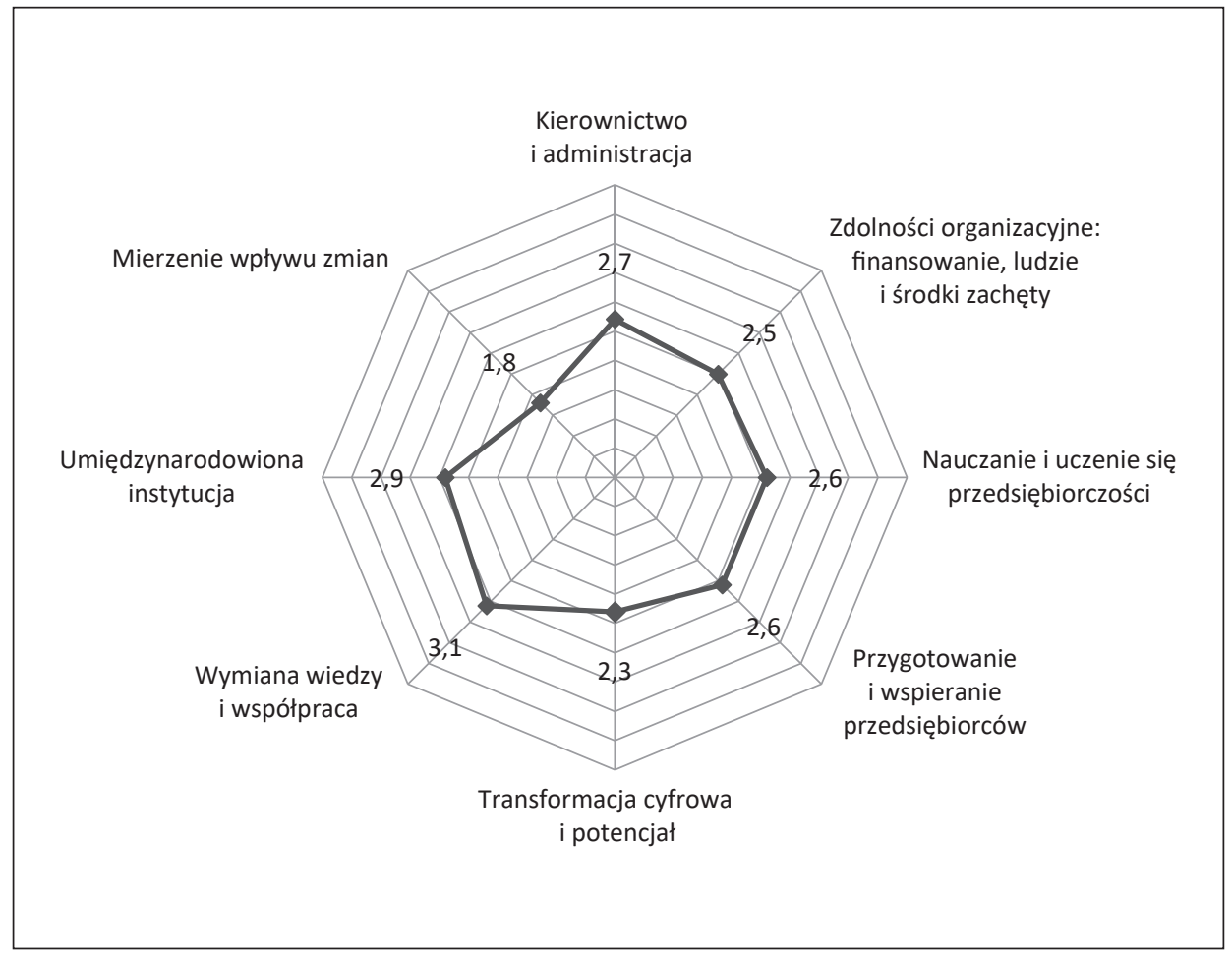

Źródło: opracowanie na podstawie badań własnych 
Wyniki badań wskazują na konieczność podjęcia inicjatyw prowadzących do intensyfikacji działań we wszystkich proponowanych w HEInnovate obszarach. Inicjatywy te polegać mogą na: 1. wprowadzaniu zmian organizacyjnych, 2. inwestowaniu w infrastrukturę i technologie (szczególnie informatyczne) oraz 3. wzmacnianiu kompetencji pracowników (tabela 1). W dalszej części artykułu zaprezentowano analizę obszarów, które w opinii respondentów wypadły najsłabiej. Przedstawiono również opisy inicjatyw usprawniających, które są kompilacją zarówno propozycji i sugestii uczestników badania, jak i doświadczeń własnych autorów, a przede wszystkim wzorcowych rozwiązań przedstawionych w kwestionariuszu HEInnovate.

Wśród trzech najniżej ocenianych przez sędziów wartościujących wymiarów wdrażania koncepcji przedsiębiorczego uniwersytetu znalazły się: 1. „zdolności organizacyjne: finansowanie, ludzie i środki zachęty”, 2. „transformacja cyfrowa i potencjał” oraz 3. „mierzenie wpływu zmian”. Wymiar „zdolności organizacyjne”: finansowanie, ludzie i środki zachęty, w ocenie respondentów uzyskał wynik na poziomie 2.5. Jest to niezmiernie istotny wymiar, gdyż decyduje o zdolności badanego podmiotu do realizacji własnych celów strategicznych. Wobec restrukturyzacji uczelni, którą wprowadzono w połowie 2019 r., oraz zmian w zakresach działań poszczególnych jednostek organizacyjnych (od kolegium przez instytuty aż po katedry) istnieje konieczność rozpoznania, czy zmiany te uwzględniają standardy (wymagania) przedsiębiorczego uniwersytetu.

Drugim spośród najsłabiej ocenionych wymiarów wdrażania koncepcji przedsiębiorczego uniwersytetu był wymiar „transformacji cyfrowej i potencjału” (przyznana ocena to 2.3). Należy zauważyć, że stopień wykorzystania technologii cyfrowych w poszczególnych jednostkach uniwersytetu jest różny. Uzyskana średnia ocena wskazuje jednak, że jednostka nie najlepiej wykorzystuje możliwości, które stwarza technologia cyfrowa. Potencjał cyfrowy instytucji, definiowany jako „zdolność do integracji, optymalizacji i transformacji technologii cyfrowych w celu wspierania innowacyjności i przedsiębiorczości" (HEInnovate) wymaga podjęcia w UEK zdecydowanych działań.

Najniższą ocenę spośród ośmiu rozpatrywanych wymiarów wdrażania koncepcji przedsiębiorczego uniwersytetu respondenci przyznali „mierzeniu wpływu zmian” (ocena 1.8). Wynik ten ewidentnie wskazuje, że w tym wymiarze jest najwięcej do poprawy w badanej jednostce. Liczenie „produktów” (np. liczby przedsiębiorstw typu spin-off, dochodów z badań) powinno być wsparte liczeniem rezultatów (np.: liczby nowo utworzonych podmiotów gospodarczych bądź miejsc pracy w wyniku uruchomienia spin-offu) oraz liczeniem oddziaływania, wpływu, czyli trwałych zmian, które spowodowały konkretne działania w otoczeniu społeczno-ekonomicznym (np. wkład w lokalny rozwój gospodarczy, zmiana struktury miejsc pracy w regionie będące skutkiem uruchomionych spin-offów).

Autorzy przyjęli założenie, że narzędzie, którym jest kwestionariusz HEInnovate, pozwoli na uzyskanie niezbędnych danych do oceny UEK jako uczelni zmierzającej do wzorca przedsiębiorczego uniwersytetu. Cele te udało się w trakcie prowadzonych badań zrealizować. Pomimo wykazanej w badaniach przeciętnej, a w niektórych obszarach stosunkowo słabej implementacji tej koncepcji w badanej jednostce warto podkreślić, że realizuje ona w tym zakresie szereg wartościowych inicjatyw. 


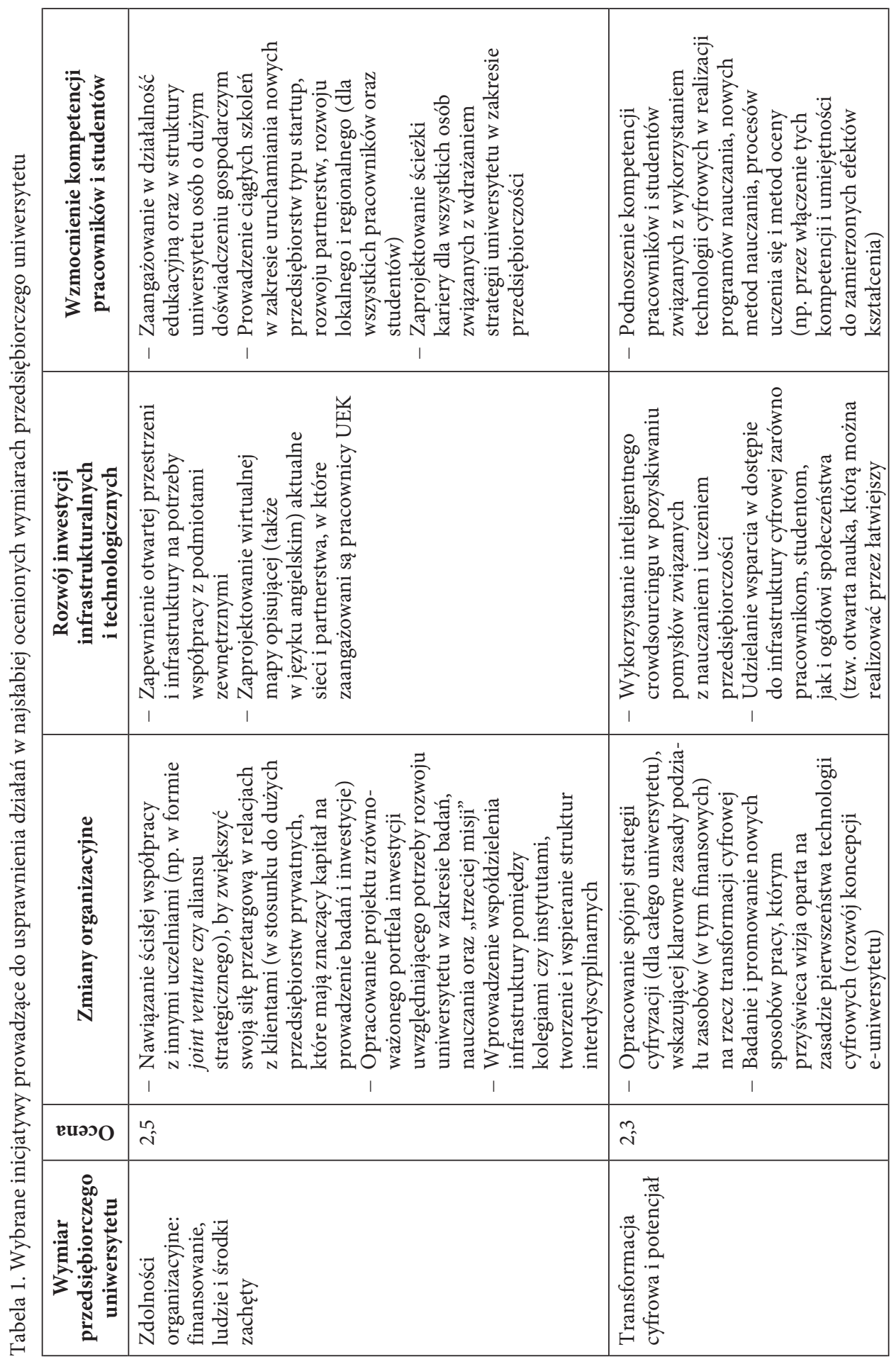




\begin{tabular}{|c|c|c|}
\hline 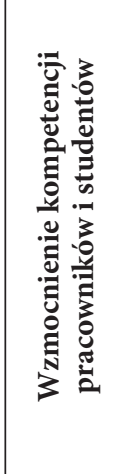 & 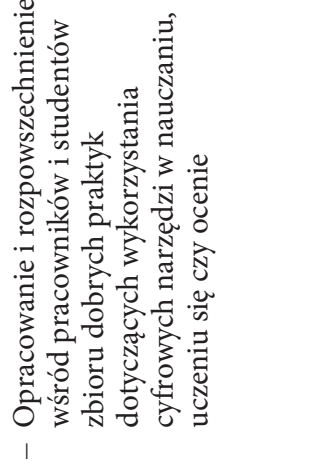 & 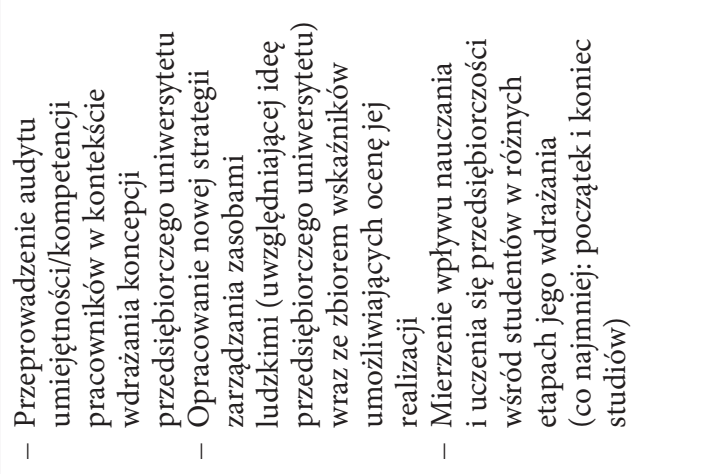 \\
\hline 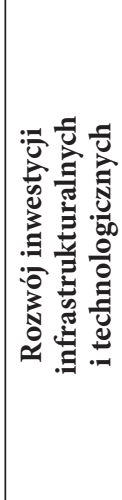 & 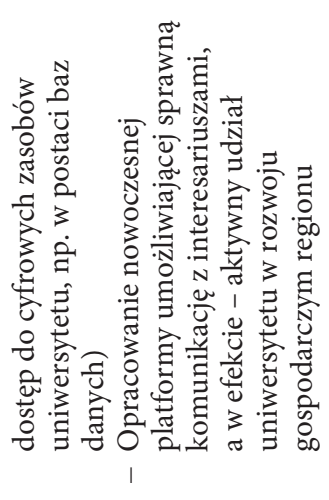 & 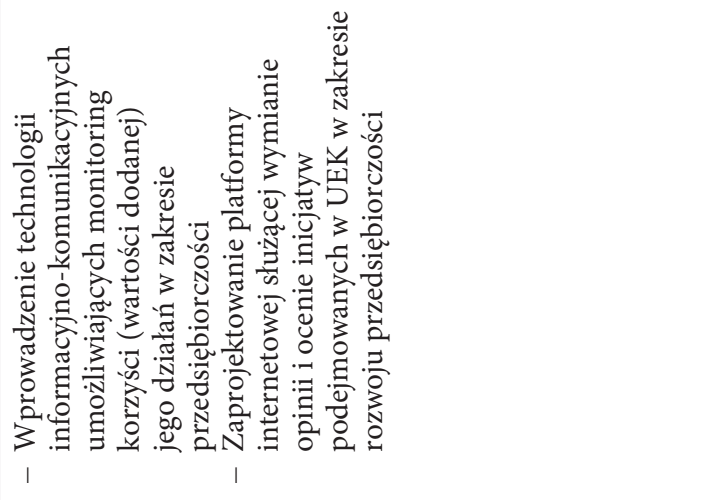 \\
\hline 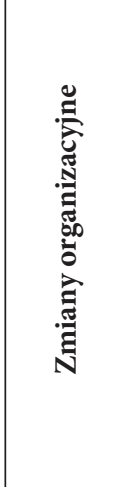 & & 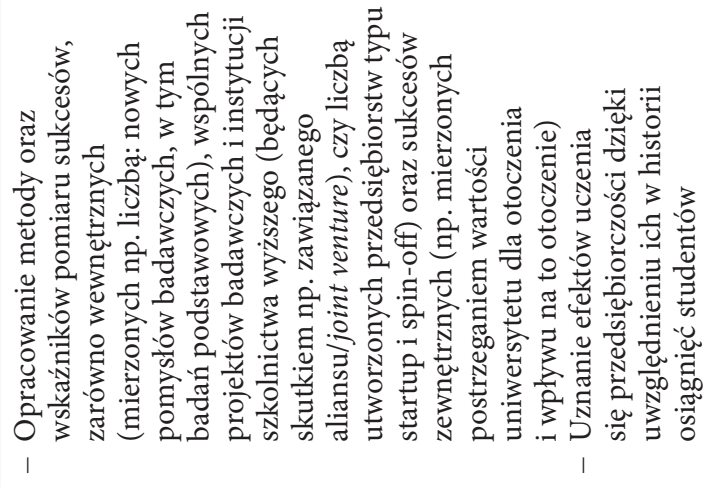 \\
\hline виәуо & & $\stackrel{\infty}{-}$ \\
\hline 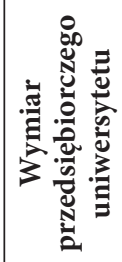 & & 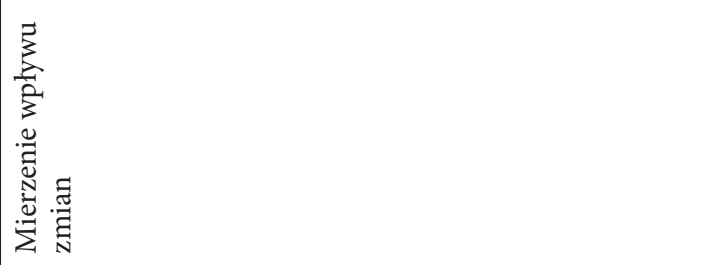 \\
\hline
\end{tabular}




\section{Zakończenie}

Ewaluacja wdrażania koncepcji przedsiębiorczego uniwersytetu dokonana na podstawie kwestionariusza HEInnovate w Uniwersytecie Ekonomicznym w Krakowie pozwoliła na ocenę ośmiu obszarów charakteryzujących przedsiębiorcze jednostki szkolnictwa wyższego. Za jego pomocą określone zostały dotychczasowe efekty działań podjętych w badanym uniwersytecie. W procesie prowadzonych badań dostrzeżono konieczność dalszego doskonalenia narzędzia, którym jest kwestionariusz HEInnovate, i dostosowania jego struktury do specyfiki ocenianej uczelni. Wyniki badań, przez odniesienie ich do wzorca przedstawionego w HEInnovate, umożliwiły wskazanie obszarów wymagających wsparcia inicjatywami służącymi budowaniu przedsiębiorczego uniwersytetu. Zaprezentowana przez autorów generalizacja wniosków - przyjmująca perspektywę interpretatywną dotyczących wdrażania koncepcji przedsiębiorczego uniwersytetu w badanej instytucji szkolnictwa wyższego może stanowić dodatkowy wkład w rozpowszechnianie wiedzy na temat tej koncepcji, a proponowane inicjatywy usprawniające służyć mogą również innym jednostkom szkolnictwa wyższego. Dalsze badania zmierzają do wypracowania kolejnych dobrych praktyk wdrażania koncepcji przedsiębiorczego uniwersytetu. Pozwoli to w przyszłości osiągnąć większą wiarygodność wyników badania (Weerd-Neederhof, 2001). Celem autorów jest również modyfikacja kwestionariusza HEInnovate za pomocą metody Participatory Action Research (Kafel, 2014), a docelowo - opracowanie projektu platformy internetowej umożliwiającej ciągłe uczenie się uczelni w zakresie rozwoju przedsiębiorczego uniwersytetu.

Literatura

References

Acs, Z.J., Braunerhjelm, P., Audretsch, D.B., Carlsson, B. (2009). The knowledge spillover theory of entrepreneurship. Small Business Economics, 32(1), 15-30.

Agrawal, A. (2006). Engaging the inventor: exploring licensing strategies for university inventions and the role of latent knowledge. Strategic Management Journal, 27(1), 63-79.

Altmann, A., Ebersberger, B. (red.) (2013). Universities in Change Managing Higher Education Institutions in the Age of Globalization. Springer.

Andrews, D., Nicoletti, G., Timiliotis, Ch. (2018). Digital technology diffusion: A matter of capabilities, incentivesorboth? OECD Economics Department Working Papers, 1476.

Borch, O.J., Rasmussen, E. (2010). University capabilities in facilitating entrepreneurship: A longitudinal study of spin-off ventures atmid-range universities. Research Policy, 39(5).

Carayannis, E.G., Barth, T.D., Campbell, D.F. (2012). The Quintuple Helix innovation model: global warming as a challenge and driver for innovation. Journal of Innovation and Entrepreneurship, 1(2). doi: https://doi.org/10.1186/2192-5372-1-2

Clark, B.R. (1998). Creating Entrepreneurial Universities: Organizational Pathways of Transformation. Oxford: Pergamon Press.

Clark, B.R. (2004a). Delineating the Character of the Entrepreneurial University. Higher Education Policy, 17, 355-370.

Clark, B.R. (2004b). Sustaining Change in Universities. Society for Research into Higher Education, Open University Press.

Czaja, I., Kafel, T. (2019). Implementation of the entrepreneurial university concept at the Cracow University of Economics. W: A. Ujwary-Gil, N. Potoczek (Eds.), Organizations in the Face of Growing Competition in the Market. Warsaw: Institute of Economics, Polish Academy of Sciences, 17-34. 
Czakon, W. (2006). Łabędzie Poppera - case studies w badaniach nauk o zarządzaniu. Przegląd Organizacji, 9, 9-12.

Ćwiklicki, M., Pilch, K. (2018). Rygor metodologiczny wielokrotnego studium przypadku w badaniach marketingu miejsc. Studia Ekonomiczne. Zeszyty Naukowe Uniwersytetu Ekonomicznego w Katowicach, 376, 23-35.

Debackere, K., Veugelers, R. (2005). The role of academic technology transfer organizations in improving industry science links. Research Policy, 34(3), 321-342.

Dębowski, H., Stęchły, W. (2019). Kształcenie dla przyszłości a kompetencje przekrojowe. W: Chmielecka E., Kraśniewska N. (red.), Edukacja dla przyszłości - jakość kształcenia, Warszaw: Polish Rector Foundation.

Drucker, P. (1986). Innovation and Entrepreneurship. Practice and Principles, Pan Books, William Heinemann, London.

Etzkowitz, H., Leydesdorff, L. (1999). The Future Location of Research and Technology Transfer, The Journal of Technology Transfer, 24(2-3), 111-123.

European Commission (2003). The role of the universities in the Europe of knowledge. $\operatorname{COM}(2003)$ 58 final, Brussels.

Friedman, J., Silberman J. (2003). University Technology Transfer: Do Incentives, Management, and Location Matter?, The Journal of Technology Transfer, 28(1), 17-30.

Gibb, A., Haskins, G., Hannon, P., Robertson, I. (2009). Leading the Entrepreneurial University. Meeting the entrepreneurial development needs of high er education institutions.

Gibb, A.A. (2013a). Developing the Entrepreneurial University of the Future. Key Challenges, Opportunities and Responses. OECD, Paris.

Gibb, A.A. (2013b). Enterprise In Education. Educating Tommorows Entrepreneurs.

Gjerding, A.N., Wilderom, C.P.M., Cameron, S.P.B., Taylor, A., Scheunert, K.J. (2006). Twenty Practices of an Entrepreneurial University. Higher Education Management and Policy, 18(2), 76-103.

Glachant, J.M, Haywood, J., Zorn, A. (2018). Higher Education in the Digital Age. Moving Academia Online. Elgar Publishing, Cheltenham.

Haller, E., Stott, L. (2010). Studium przypadku - poradnik. Kraków: Wydawnictwo Spektrum.

HEInnovate (2018). The Entrepreneurial and Innovative Higher Education Institution. A Review of the Concept and Its Revelance Today.

Hytti, U., Blackburn, R., Laveren, E. (2018). Entrepreneurship, Innovation and Education. Frontiers in European Entrepreneurship Research. Elgar Publishing, Cheltenham.

Jørgensen, T., (2019). Digital skills - Where universities matter, Learning and Teaching Paper. The European University Association, 7.

Kafel, T., (2014). Metody profesjonalizacji organizacji pozarządowych. Zeszyty Naukowe, Seria specjalna: Monografie. Uniwersytet Ekonomiczny w Krakowie, 235.

Kusio, T., (2019). Więzi relacyjne uczelni z biznesem. Kraków: Wydawnictwo Akademii Górniczo-Hutniczej w Krakowie.

Kwiek, M. (2015). Academic Entrepreneurialism and Changing Governance in Universities. Evidence from Empirical Studies.

Makieła, Z.J., (2017). Model Uniwersytetu Trzeciej Generacji XXI wieku - przedsiębiorczy, innowacyjny uniwersytet. Folia Oeconomica Cracoviensia, PAN, LVIII, 23-38.

Matejun, M. (2012). Metoda studium przypadku - egzemplifikacja wykorzystania w naukach o zarządzaniu. Studia Ekonomiczne Regionu Łódzkiego, 7.

Meyer-Guckel, V., Klier, J., Kirchherr, J., Winde, M. (2019). Futureskills: Strategische Potenziale für Hochschulen, Discussion Papier, 3.

Mizerek, H., (2017). Studium przypadku w badaniach nad edukacją. Istota i paleta zastosowań. Olsztyn: Uniwersytet Warmińsko-Mazurski.

OECD. (2012). Edukacja w skrócie 2012: Wskaźniki OECD. Paryż: OECD Publishing.

Olearnik, J., Pluta-Olearnik, M. (2015). Entrepreneurial University - From Ideas to Reality. Optimum. Studia Ekonomiczne, 5(77), 110-120. 
Pluta-Olearnik, M. (red.). (2009). Przedsiębiorcza uczelnia i jej relacje z otoczeniem. Warszawa: Difin.

Rachwał, T. (red.). (2019). Kształtowanie kompetencji przedsiębiorczych. Seria Naukowa, t. 5. Warszawa: Wydawnictwo FRSE.

Segrera, L. (2010). Trends and Innovations in Higher Education Reform: Worldwide, Latin America and in the Caribbean, University of California, Berkley. Research \& Occasional Paper, Series: CSHE.12.10.

Seliga, R., Sułkowski, Ł. (2016). Przedsiębiorczy uniwersytet - zastosowanie zarządzania strategicznego. Prace Naukowe Uniwersytetu Ekonomicznego we Wrocławiu, 444, 478-489.

Shane, S.A. (2004). Academic entrepreneurship: University spinoffs and health creation. Cheltenham, UK/Northampton, MA, USA. Elgar Publishing.

Shattock, M. (2010). The Entrepreneurial University: An Idea for Its Time. London Review of Education, $8(3), 263-271$.

Sporn, B. (1996). Managing University Culture: An Analysis of the Relationship Between Institutional Culture and Management Approaches. Higher Education, 32(1), 41-61.

Sporn, B. (2001). Building Adaptive Universities: Emerging Organisational Forms Based on Experiences of European and US Universities. Tertiary Education and Management, 7, 121-134. doi: https://doi.org/10.1023/A:1011346201972

Sułkowski, Ł. (2014). Który model uniwersytetu?, Głosy w dyskusji. Przegląd Socjologiczny, 63(3), 67-70. Watson, D. (2010). Universities' Engagement with Society. W: B. Mc Gaw, P. Peterson, E. Baker (red.), The International Encyclopedia of Education. Elsevier.

Weerd-Nederhof, P. (2001). Qualitative Case Study Research. The Case of a PhD Research Project on Organising and Managing New Product Development Systems. Management Decision, 39(7), 513-538.

Williams, G. (1992). Changing Patterns of Finance in Higher Education. Buckingham: Open University Press.

Wissema, J.G. (2009). Towards the Third Generation University. Managing the University in Transition. Edward Elgar Publishing.

Yin, R.K. (2015). Studium przypadku w badaniach naukowych: projektowanie i metody. Kraków: Wydawnictwo UJ.

Yin, R.K. (2009). Case Study Research. Design and Methods. Sage Publications.

Zalecenie Rady z dnia 22 maja 2018 w sprawie kompetencji kluczowych w procesie uczenia się przez cate życie (Tekst mający znaczenie dla EOG), Dz.UE 2018/C 189/01

Zioło, Z. (2016). Zarys uwarunkowań kształtowania przedsiębiorczego uniwersytetu, Horyzonty Wychowania, 15(35), 29-54.

Izabela Czaja, dr, Uniwersytet Ekonomiczny w Krakowie, Wydział Ekonomii i Stosunków Międzynarodowych, Katedra Przedsiębiorczości i Innowacji. Doktor nauk ekonomicznych. Jej zainteresowania naukowe i badawcze obejmują obszary związane z tematyką działalności gospodarczej, takie jak: przedsiębiorczość, ekonomia ewolucyjna, mikroekonomia, historia myśli ekonomicznej, prawne i podatkowe uwarunkowania prowadzenia działalności gospodarczej, modelowanie rozwoju małej i średniej firmy, innowacje, innowatyka, międzynarodowe stosunki gospodarcze, dynamika rozwoju sektora prywatnego, sektor MŚP w Polsce i na świecie.

Izabela Czaja, $\mathrm{PhD}$, Cracow University of Economics, Faculty of Economics and International Relations, Department of Entrepreneurship and Innovativeness. PhD in Economics. Her research interests cover the issue of economic activity, in particular: entrepreneurship, evolutionary economics, microeconomics, the history of economic thought, legal and fiscal conditions for economic activity, development modelling for small and medium business, innovations, innovativeness, international business relations, the dynamics of private sector development, SME sector in Poland and in the world.

ORCID: https://orcid.org/0000-0002-2243-848X 


\section{Adres/Address:}

Uniwersytet Ekonomiczny w Krakowie

Katedra Przedsiębiorczości i Innowacji

ul. Rakowicka 27

31-510 Kraków, Polska

e-mail: czajai@uek.krakow.pl

Tomasz Kafel, dr hab., prof. UEK, Uniwersytet Ekonomiczny, Katedra Metod Organizacji i Zarządzania. Jego zainteresowania badawcze koncentrują się na zarządzaniu organizacjami non-profit oraz zarządzaniu strategicznym, metodach twórczego myślenia oraz metodologii organizacji i zarządzania.

Tomasz Kafel, associate professor, Cracow University of Economics, Department of Organization and Management Methods. He is focused especially on research in the field of non-profit organisations management, strategic management, creative thinking methods, methodology of organisation and management.

ORCID: https://orcid.org/0000-0003-2931-1921

\section{Adres/Address:}

Uniwersytet Ekonomiczny w Krakowie

Katedra Metod Organizacji i Zarządzania

ul. Rakowicka 27

31-510 Kraków, Polska

e-mail: kafelt@uek.krakow.pl

Publikacja została dofinansowana ze środków przyznanych Katedrze Metod Organizacji i Zarządzania oraz Katedrze Przedsiębiorczości i Innowacji Uniwersytetu Ekonomicznego w Krakowie w ramach dotacji na utrzymanie potencjału badawczego. 